\title{
Different Types of Fee Calculations on the RCBS Market in the Czech Republic
}

\author{
Martin MATĚJÍČEK ${ }^{* *}$ and Anna S. KOWALSKA ${ }^{2}$ \\ 1 University of Hradec Králové, Hradec Králové, Czech Republic; martin.matejicek@uhk.cz \\ 2 Wroclaw University of Economics and Business, Wroclaw, Poland; anna.kowalska@ue.wroc.pl \\ * Corresponding author: martin.matejicek@uhk.cz
}

\begin{abstract}
Nowadays, almost everyone uses banking services. However, there is room in the market for bad decision-making by clients in the RCBS market, which is caused by information asymmetries. The main goal of this paper is to simulate consumer behavior and compare the offer in the banking services market in the Czech Republic. A total of 9 different payment accounts were selected for the research, which are intended for non-business natural persons. Furthermore, two customer groups were defined, for which the fees for the mentioned payment accounts were subsequently calculated on the basis the intensities of the use of certain services. In general, it was found that the stochastic calculation is more different than the deterministic one, especially for accounts and services that contain a certain condition, and the intensity of use is close to the transitional limit of this condition. On the contrary, in the case of bank calculators, the differences compared to the calculation from the tariffs were too large, and there was also a considerable mixing of the order according to the price.
\end{abstract}

Keywords: RCBS; consumer behaviour; banking services; stochastic simulation; online comparison tool

\section{JEL Classification: C15; G21}

\section{Introduction}

Nowadays, almost everyone uses banking services. However, there is room in the market for bad decision-making by clients in the RCBS market, which is caused by information asymmetries. Banks have complex rates and it is not worthwhile for the client to study these rates in detail and compare the differences due to time constraints. However, consumers can use online applications to calculate the prices of specific banking products. This paper will examine how the results of calculators differ from reality and it also pays attention to the stochastic simulation of the client and the difference in the result compared to deterministic reasoning. The topic of probabilistic model in the RCBS market has already been addressed by, for example, the authors Hedvicakova et al. (2012).

Information asymmetries occur when one party in the market has better information than the other (Sojka, 2002). Currently, this problem is one of the causes of market failure. The American economist George Akerlof pointed out this problem as early as 1970, in his publication called "The Market for 'Lemons': Quality Uncertainty and the Market Mechanism" (Akerlof, 1970). 
As already mentioned, information asymmetries also appear in the RCBS market. The problem is mainly on the demand side, where the consumer does not have simple and clear prices that are linked to basic banking services. Banks usually make their rates very nontransparent and complicated. Soukal and Draessler (2014) discuss the asymmetry of information in the RCBS market in more detail. The client's effort to obtain the required information can therefore be relatively mentally and time consuming.

The main goal of this paper is to simulate consumer behavior and compare the offer in the banking services market. For example, Hedvicakova (2017) made a similar comparison on the market in the Czech Republic, but her study was focused only on student's accounts. Our goal is further elaborated mainly on the approximation of selected payment accounts on the market, on the calculation of bank fees in different ways for certain client profiles and on the interpretation of differences in the results of given calculation methods.

Using multi-criteria optimization and fuzzy analysis this article aims to select the most suitable bank account for young people. Two scientific questions are asked: Is the same type of student account suitable for an active as well as an inactive client? Are there any free of charge student accounts? The first part focuses on the introduction to the topic, a summary of the advantages and disadvantages of student accounts and modelling of two target groups. The second part describes the methodology of decision-making by using a fuzzy set theory. Selection of the optimum student account will be made by the transformation matrix. Subsequently, the retransformation matrix is set. The most suitable student accounts are again selected for each profile and the results are compared with the analysis in the first part. To complete the solution, the last part of the article focuses on decision-making with the uncertainty of input information. Due to ignorance of their own monthly needs and the number of payments, fuzzy sets are used. In addition to the active and passive client, a third profile will be newly created and can be identified with some of the profiles to a certain extent.

\section{Methodology}

The total number of 9 banking institutions were selected to calculate the fees. One specific payment account was selected from each bank, which is intended for non-business natural persons, and the basic fees associated with the use of the account were determined according to the price lists. Specifically, the payment accounts "Air Bank Maly tarif", "ČS Moje zdravé finance", "ČSOB Plus Konto", "Fio osobní účet", "KB Mưjúčet", "mBanka mKonto", "MONETA Tom účet", "RFB eKonto Smart" and "UCB U konto" were selected.

To calculate the fees, it is first necessary to define the intensity of use of individual banking services. Data from the research of Draessler et al. (2011) are used for this purpose. These are the intensities of the use of retail banking, the services of which are used by nonbusiness natural persons. Data collection took place through the portal www.bankovnipoplatky.com. It was therefore assumed that the respondents were information literate and had access to the Internet. The aim of the research was to classify the 
clients of Czech banks and to define the basic groups in relation to transactions on client accounts.

The first profile was marked as the average internet banking client, resp. Mainstream making up more than $62 \%$ of the total. His preference for this information channel is very strong. This client does not withdraw foreign banks from the ATM (automated teller machine) and it can therefore be argued that within these clients there was a fee diversification, resp. gradual increase in prices of withdrawals from ATMs of foreign banks, successful. The share of transfer services between sending funds to the accounts of own and foreign banks is approximately 1:2. (Draessler et al., 2011)

The second profile was marked as the average client with branch preference. Although it is a relatively small cluster $(4 \%)$, it cannot be described as a low-element cluster composed only of remote observations without interpretive value. Its activity is practically identical to the average client, but the main difference is the choice of communication channel, where the occasional visit to a bank branch on average once every three months is preferred. Thus, there is a group of clients with active internet banking, who still sometimes prefer to visit a branch for normal operations. (Draessler et al., 2011)

Table 1. Used client profiles. (Draessler et al., 2011)

\begin{tabular}{|c|c|c|}
\hline Service & I1 & I2 \\
\hline Minimum credit turnover & CZK 21,120 & CZK 17,409 \\
\hline Average balance & CZK 22,103 & CZK 23,428 \\
\hline Withdrawal from ATM from own bank in the Czech Republic & 2.9 & 3.1 \\
\hline Withdrawal from ATM from foreign bank in the Czech Republic & 0 & 0.5 \\
\hline Withdrawal from ATM from f. b. - amount & 0 & CZK 815 \\
\hline Withdrawal from ATM abroad (EU) & 0 & 2 \\
\hline Incoming payment from foreign bank & 2.2 & 2.0 \\
\hline Incoming payment from own bank & 0.9 & 1.0 \\
\hline Single PO to own bank at the branch & 0 & 0.3 \\
\hline Single PO to own bank from the Internet & 1.8 & 1.8 \\
\hline Single PO to foreign bank at the branch & 0 & 0.3 \\
\hline Single PO to a foreign bank from the Internet & 3.8 & 3.2 \\
\hline Standing PO to own bank at the branch & 0 & 0.2 \\
\hline Standing PO to own bank from the Internet & 0.9 & 0.7 \\
\hline Standing PO to foreign bank at the branch & 0 & 0.2 \\
\hline Standing PO to foreign bank from the Internet & 2.4 & 1.7 \\
\hline DD payment to own bank at the branch & 0 & 0.2 \\
\hline DD payment to own bank from the Internet & 0.3 & 0.2 \\
\hline DD payment a foreign bank at the branch & 0 & 0.3 \\
\hline DD payment to a foreign bank from the Internet & 0.9 & 0.5 \\
\hline Cash deposit at the branch & 0.2 & 0.5 \\
\hline Cash withdrawal at the branch & 0.1 & 0.3 \\
\hline Incoming SEPA payment up to 50 thousand EUR & 0 & 1.0 \\
\hline Outgoing SEPA payment up to 50 thousand EUR & 0 & 1.0 \\
\hline
\end{tabular}

I1 = use intensity for the 1st selected client profile; I2 = use intensity for the 2nd selected client profile; $\mathrm{PO}=$ payment order; $\mathrm{DD}=$ direct debit.

For the needs of simulation in this research, a selection from ATM abroad (EU, twice a month), incoming SEPA payment up to EUR 50 thousand (once a month) and outgoing SEPA 
payment up to EUR 50 thousand (once a month) were added to the 2 nd variant profile. The data are clearly summarized in the following table of client profiles.

Some bank account rates contain additional conditions for calculating the price or discount for certain services. For this reason, the following data are also set for the needs of the research, which apply to both client profiles:

- average card payment 5 times a month,

- $\quad$ average amount of card payments = CZK 4,000 per month,

- average amount of withdrawal from own ATM in the Czech Republic $=$ CZK 1,500,

- average amount of withdrawal from ATM abroad = CZK 815,

- amount of outgoing payments and deposits min. CZK 10,000

- min. outgoing payment 3 times a month,

- client's age 26-58 years.

The fees were calculated on the basis of bank tariffs for defined customer groups. Calculations are performed deterministically and stochastically with the help of a Microsoft Excel spreadsheet. The deterministic calculation consists in simply multiplying the fee by the respective intensity of use of the given service and the given client profile. The Monte Carlo simulation method was used for the stochastic calculation, and an add-on in Excel called "Data Analysis" was chosen as a generator of pseudo-random numbers.

Skalská (2006) states that the Monte Carlo method belongs to the sector of experimental mathematics, which deals with experiments with random numbers. It can be used to solve statistical, mathematical or even non-mathematical simulation problems with the help of random selections. The method consists in repeating a certain random experiment (simulation) several times. However, the condition for success is the possibility of independent multiple retries. This approach in the field of banking was used, for example, by Král (2017a, 2017b), when calculating the costs of cash processing.

The Monte Carlo test in this study contains a total of 10 simulation series, each of which simulates the client's behavior of each service for 60 months. Pseudorandom numbers for simulation of service use intensities are generated with a Poisson's type of probability distribution, and the intensity of use of a given service of a certain client profile is chosen as a key parameter $\lambda$ (lambda). New series have been generated for each service and each client profile. The final amount of the fee of each service is then calculated by averaging all ten simulation series (600 pseudo-random numbers - 600 monthly fee amounts).

For some services of selected accounts, the account balance, the amount of withdrawals from ATMs or the total monthly amount for card payments are also simulated. For these calculations, the Student's probability distribution is chosen, and the numbers are generated using a formula in Excel.

The last type of fee calculation for specified customer profiles are online calculators. The calculators Bankovnipoplatky.com and Finparáda were chosen for the calculation. 


\section{Results}

For the first client profile, the average difference (in absolute value) in the method of calculation is CZK 6.52, see the following table 2. The biggest difference is with the mBank mKonto account, and with the Air Bank Malý tarif. In the first case, there was the biggest difference in the ATM withdrawal service from your own bank in the Czech Republic, where a fee of CZK 29 is charged for withdrawing cash up to CZK 1,500. Withdrawals above CZK 1,500 are free. In the Monte Carlo test, the intensity of the withdrawal and the selected amount were simulated, where the pseudo-random number generator generated amounts with the parameter $\mathrm{k}=\mathrm{CZK} 1,500$, which is the very limit of the condition that decides whether the withdrawal will be charged or not. There was a difference of CZK 6.71 for the Air Bank Malý tarif account thanks to the interest bonus simulation. If the client uses a card payment 5 times a month in a store or on the Internet, as a bonus, the account will earn interest at a rate of $1 \%$ per annum. In the deterministic calculation, this bonus was awarded every month, as the average intensity of payment card use was entered 5 times a month for both client profiles. The stochastic calculation simulated the intensity of payment card use (Poisson distribution, $\lambda=5$ ), as well as the balance from which interest is calculated (student distribution, $\mathrm{k}=59$ degrees of freedom, $\left.{ }^{*} \mathrm{CZK} 22,103\right)$.

Table 2. Comparison of deterministic and stochastic calculation for the 1st profile.

\begin{tabular}{|c|c|c|c|}
\hline Profile 1 & DET & STO & I Difference I \\
\hline Air Bank M.t. & -18.42 CZK (1.) & -7.15 CZK (1.) & 11.27 CZK \\
\hline Fio osobní účet & 0 CZK (2.) & 0 CZK (2.) & 0 CZK \\
\hline RFB eKonto S. & 0 CZK (3.) & 2.04 CZK (3.) & 2.04 CZK \\
\hline ČSOB Plus Konto & 8 CZK (4.) & 7.73 CZK (4.) & 0.27 CZK \\
\hline UCB U konto & 10 CZK (5.) & 9.67 CZK (5.) & 0.33 CZK \\
\hline MONETA Tom ú. & 24 CZK (6.) & 24.93 CZK (6.) & 0.93 CZK \\
\hline KB MůjÚčet & 68.1 CZK (7.) & 69.25 CZK (8.) & 1.15 CZK \\
\hline ČS MZF & 71.4 CZK (8.) & 72.79 CZK (9.) & 1.39 CZK \\
\hline mBank mKonto & 87 CZK (9.) & 59.01 CZK (7.) & 27.99 CZK \\
\hline AVERAGE & 27.79 CZK & 24.62 CZK & 6.71 CZK \\
\hline
\end{tabular}

$\mathrm{DET}=$ deterministic calculation; $\mathrm{STO}=$ stochastic calculation .

Air Bank Malý tarif proved to be the cheapest account here. The price is negative - the client is rewarded with this amount. In the overall ranking, there was only one difference in the simulation compared to the deterministic calculation - mBank mKonto changed its position from 9th place to 7 th place.

In the case of the second profile (Table 3), there was an average difference (in absolute value) in the method of calculation of CZK 8.97. The biggest difference is with the account from mBank. The reason for the main factor of the difference has already been mentioned for the first profile. There was also an above-average difference in the account from Česká spořitelna (CZK 11.68). The difference here is mainly the selection of ATMs abroad and SEPA payments. An optional service was included for withdrawals abroad (for CZK 25 per month, the client has foreign withdrawals from the Erste Group ATM free of charge and CZK 40 is charged at other banks for withdrawals). For the deterministic calculation, 1 withdrawal per 
month was calculated for Erste and 1 withdrawal per month for other banks. However, the stochastic calculation simulated these values by generating pseudorandom numbers. The second main source of difference was SEPA payments. An optional service for CZK 25 per month was applied here. This package then includes 2 free incoming payments and 2 outgoing payments for CZK 40. The difference in price therefore arose in the case of generating higher numbers than the package benefits.

Table 3. Comparison of deterministic and stochastic calculation for the 2nd profile.

\begin{tabular}{|c|c|c|c|}
\hline Profile 2 & DET & STO & IDifference I \\
\hline Fio osobní účet & 160.8 CZK (1.) & 164.1 CZK (1.) & $3.3 \mathrm{CZK}$ \\
\hline ČS MZF & 289.4 CZK (2.) & 277.72 CZK (2.) & $11.68 \mathrm{CZK}$ \\
\hline MONETA Tom ú. & 429.4 CZK (3.) & 429.13 CZK (3.) & $0.27 \mathrm{CZK}$ \\
\hline UCB U konto & 544.2 CZK (4.) & 545.2 CZK (4.) & $1 \mathrm{CZK}$ \\
\hline RFB eKonto $S$. & 590.8 CZK (5.) & 592.7 CZK (5.) & $1.9 \mathrm{CZK}$ \\
\hline KB MůjÚǔčt & 663.4 CZK (6.) & 661.76 CZK (6.) & $1.64 \mathrm{CZK}$ \\
\hline ČSOB Plus Konto & 674 CZK (7.) & 683.87 CZK (7.) & 9.87 CZK \\
\hline Air Bank M.t. & $\mathrm{N}-132.02 \mathrm{CZK}$ & $\mathrm{N}-121.27 \mathrm{CZK}$ & 10.75 CZK \\
\hline mBank mKonto & N - 171.1 CZK & $\mathrm{N}-130.74 \mathrm{CZK}$ & 40.36 CZK \\
\hline AVERAGE & $478.86 \mathrm{CZK}$ & 479.21 CZK & 8.97 CZK \\
\hline
\end{tabular}

$\mathrm{DET}=$ deterministic calculation; $\mathrm{STO}=$ stochastic calculation .

Note: Accounts highlighted in red do not support the branch operations that are included in the second profile. They are not listed in the overall ranking, but they are included in the calculation of the averages.

Fio personal account turned out to be the cheapest account here. Accounts from Air Bank and mBank were excluded from the overall ranking due to the absence of operations at the branch, which are otherwise an integral part of the second client profile. There was no order change for the remaining accounts due to the method of calculation.

The third type of calculation was calculation using online calculators. The calculators Bankovnípoplatky.com and Finparáda were selected. Both calculators have a different structure and do not allow entering intensities to decimal places. Therefore, the data had to be slightly adjusted and rounded. The results for the first profile are in the following Table 4 .

Table 4. Comparison of deterministic calculation with online calculators for the 1st profile.

\begin{tabular}{|c|c|c|c|c|c|}
\hline Profile 1 & DET & BP.COM & IDifference I & FINPARÁDA & IDifference I \\
\hline Air Bank M.t. & -18.42 CZK (1.) & 0 CZK (1.-3.) & 18.42 CZK & -15.66 CZK (1.) & 2.76 CZK \\
\hline Fio osobní účet & 0 CZK (2.) & 0 CZK (1.-3.) & 0 CZK & 0 CZK (3.-7.) & 0 CZK \\
\hline RFB eKonto S. & 0 CZK (3.) & 29 CZK (4.) & 29 CZK & 0 CZK (3.-7.) & 0 CZK \\
\hline ČSOB Plus Konto & 8 CZK (4.) & 80 CZK (5.) & 72 CZK & 0 CZK (3.-7.) & 8 CZK \\
\hline UCB U konto & 10 CZK (5.) & 117 CZK (6.) & 107 CZK & -0.15 CZK (2.) & 10.15 CZK \\
\hline MONETA Tom ú. & 24 CZK (6.) & 119 CZK (7.) & 95 CZK & 0 CZK (3.-7.) & 24 CZK \\
\hline KB Mújúǔet & 68.1 CZK (7.) & 168 CZK (9.) & 99.9 CZK & 66 CZK (9.) & 2.1 CZK \\
\hline ČS MZF & 71.4 CZK (8.) & 130 CZK (8.) & 58.6 CZK & 50 CZK (8.) & 21.4 CZK \\
\hline mBank mKonto & 87 CZK (9.) & 0 CZK (1.-3.) & 87 CZK & 0 CZK (3.-7.) & 87 CZK \\
\hline AVERAGE & 20.39 CZK & 71.44 CZK & 62.99 CZK & 11.13 CZK & 20.36 CZK \\
\hline
\end{tabular}

DET = deterministic calculation; BP.COM = Bankovnípoplatky.com. 
For red product prices, the calculator stated that the calculated fees for opening and maintaining a given account do not include items that the account does not offer. In the case of the first profile, Air Bank Malý tarif would be the absence of a withdrawal and deposit at a branch that the bank does not allow. In the deterministic calculation of Air Bank, for the needs of this study, this service was replaced by ATM withdrawal and deposit, as the ATM is available at each branch and supports withdrawals and cash deposits. However, the calculator marked other products in this way, probably because it does not include the amount for the basic non-embossed payment card in its internal tariff. Some monitored accounts offer the issuance and maintenance of an embossed payment card free of charge and do not offer non-embossed cards at all - for example, Fio banka. If the consumer enters a nonembossed card into the calculator, the calculator should rather react by including the embossed card if the non-embossed card is not offered. For all monitored accounts, at least one card is available free of charge (issue and maintenance), whether embossed or nonembossed.

In this case, this designation can be ignored and the order within the given calculation is given for all monitored accounts. However, on the calculator portal itself, the accounts marked in red were placed only at the end of order, which certainly has an impact on consumer decisions.

For the first client profile, the average difference (in absolute value) compared to the calculation from the current tariffs is CZK 71.44 for the Bankovnípoplatky.com calculator and CZK 20.36 for the Finparáda calculator. In the case of both calculators, there was also a considerable mixing of the order. According to Finparáda, the cheapest account is Air Bank Malý tarif. According to Bankovnípoplatky.com, there are three accounts on the first place with a final price of CZK 0 - Air Bank Malý tarif, Fio osobní účet and mBank mKonto.

For the second client profile (Table 5), the average difference (in absolute value) compared to the calculation from the current tariffs is CZK 136.01 for the Bankovnípoplatky.com calculator and CZK 144.64 for the Finparáda calculator. Here, also, the order of the two calculators was significantly mixed. The cheapest account for this profile is Fio osobní účet according to both calculators.

Table 5. Comparison of deterministic calculation with online calculators for the 2nd profile.

\begin{tabular}{|c|c|c|c|c|c|}
\hline Profile 2 & DET & BP.COM & I Difference I & FINPARÁDA & I Difference I \\
\hline Fio osobní účet & 160.8 CZK (1.) & 258 CZK (1.) & 97.2 CZK & 268.15 CZK (1.) & 107.35 CZK \\
\hline ČS MZF & 289.4 CZK (2.) & 700 CZK (4.) & 410.6 CZK & 465.3 CZK (2.) & 175.9 CZK \\
\hline MONETA T. ú. & 429.4 CZK (3.) & 518 CZK (2.) & 88.6 CZK & 492.65 CZK (3.) & 63.25 CZK \\
\hline UCB U konto & 544.2 CZK (4.) & 667 CZK (3.) & 122.8 CZK & 549.83 CZK (4.) & 5.63 CZK \\
\hline RFB eKonto S. & 590.8 CZK (5.) & 707 CZK (5.) & 116.2 CZK & 678.15 CZK (6.) & 87.35 CZK \\
\hline KB MůjÚčet & 663.4 CZK (6.) & 778 CZK (7.) & 114.6 CZK & 668 CZK (5.) & 4.6 CZK \\
\hline ČSOB Plus K. & 674 CZK (7.) & 770 CZK (6.) & 96 CZK & 1420 CZK (7.) & 746 CZK \\
\hline Air Bank M.t. & 132.02 CZK & 125 CZK & 7.02 CZK & 108.41 CZK & 23.61 CZK \\
\hline mBank mKonto & 171.1 CZK & 0 CZK & 171.1 CZK & 83 CZK & 88.1 CZK \\
\hline AVERAGE & 406.12 CZK & 502.56 CZK & 136.01 CZK & 525.94 CZK & 144.64 CZK \\
\hline
\end{tabular}

$\mathrm{DET}=$ deterministic calculation; BP.COM = Bankovnípoplatky.com. 
In the deterministic calculation from the tariff, the red color indicates the absence of branch operations at Air Bank and mBank. Branch operations are an integral part of the second profile, so these accounts are not ranked, but are not excluded from the calculation of averages. The red coloring of other accounts from the Bankovnípoplatky.com calculator has already been addressed in the previous table. Finparáda did not even point out the absence of branch operations in the given accounts, which is a big mistake.

\section{Discussion and Conclusion}

The main part of the paper was the interpretation of the results and a comparison of differences in the method of calculating fees associated with accounts. Air Bank Malý tarif was the cheapest account for the first client profile. This was confirmed by a deterministic and stochastic calculation from tariffs, as well as by the fee calculators Bankpoplatky.com and Finparáda. For the second client profile, this was the case with Fio osobní účet account.

Overall, this research found that the stochastic calculation is more different than the deterministic one, especially for accounts and services that contain a certain condition, and the intensity of use is close to the transitional limit of this condition. Fluctuations in the calculation could also occur when using large intensities and when simulating a short simulation series. In general, however, the difference is usually negligible, the stochastic calculation changed the order of services by price for only one payment account for the first client profile. The average absolute value of the difference against the deterministic calculation is only CZK 7.84 in total.

On the contrary, in the case of bank calculators, the differences were too large compared to the calculation from the tariffs (the average of the absolute value of the difference is a total of CZK 91), and there was also a considerable mixing of the order according to price. In most cases, the consumer selects the product according to the final order. In addition, the Bankovnípoplatky.com calculator misjudges the payment card requirement and the Finparáda does not point out the absence of certain required services of the given accounts. So far, the main problem is the quality and settings of online calculators. Soukal (2019) also confirmed this idea.

All this points to significant shortcomings of the calculators, although they should, according to Directive 2014/92 / EU of the European Parliament and of the Council, provide accurate and up-to-date information.

This study focused on the calculation of fees. However, it is important to mention that clients do not always decide only on the basis of price. A number of other factors play a role here, such as image, seriousness, loyalty, public speaking, and so on. Many authors agree with this, for example Amoako et al. (2017), Soukal and Draessler (2015), Shafee et al. (2017) and Shahrinaz et al. (2017).

Acknowledgments: The work was supported by the internal project "SPEV - Economic Impacts under the Industry 4.0 / Society 5.0 Concept", 2021, University of Hradec Králové, Faculty of Informatics and Management, Czech Republic. 


\section{References}

Akerlof, G. A. (1970). The Market for "Lemons": Quality Uncertainty and the Market Mechanism*. The Quarterly Journal of Economics, 84(3), 488-500. https://doi.org/10.2307/1879431

Amoako, G. K., Anabila, P., Asare Effah, E., \& Kumi, D. K. (2017). Mediation role of brand preference on bank advertising and customer loyalty: A developing country perspective. International Journal of Bank Marketing, 35(6), 983-996. https://doi.org/10.1108/IJBM-07-2016-0092

Draessler, J., Soukal, I., \& Hedvicakova, M. (2011). Shluková analýza poptávkové strany trhu základních bankovních služeb. EEM: Ekonomie a Management, 14(4), 102-114.

Hedvicakova, M. (2017). Key study of bank accounts for young people with using multi-criteria optimization and fuzzy analysis. Applied Economics, 49(36), 3599-3610. https://doi.org/10.1080/00036846.2016.1265073

Hedvicakova, M., Soukal, I., \& Draessler, J. (2012). Probabilistic model of optimal price search on the retail core banking services market. International Journal of Mathematical Models and Methods in Applied Sciences, 6(2), 386-393.

Kral, M. (2017a). Modelling of Savings in Decentralized Cash Processing Costs in the Czech Republic. In P. Jedlicka, P. Maresova, \& I. Soukal (Eds.), 15th International Scientific Conference on Hradec Economic Days 2017 (pp. 478-485). Hradec Králové: University of Hradec Králové.

Kral, M., \& Hajek, L. (2017b). Modelling and Optimization Cash Processing Costs in the Czech Republic. In P. Novak, Z. Jurigova, L. Kozubikova, \& J. Zlamalova (Eds.), 8th International Scientific Conference on Finance and Performance of Firms in Science, Education and Practice (pp. 420-433). Zlin: Tomas Bata University Zlin.

Shafee, N. B., Suhaimi, S., Hashim, H., \& Mohamed, Z. S. (2017). Customer Preferences in Selecting Commercial Bank in Malaysia. Advanced Science Letters, 23(11), 10925-10928. https://doi.org/10.1166/asl.2017.10188

Shahrinaz, I., Kasuma, J., Naim, A. S. A., Rahim, E. A., Arabi, A., Ismawi, N., \& Rosli, R. (2017). Determinant of customers' preference in selecting Islamic banks. International Journal of Advanced and Applied Sciences, 4(3), 117-121. https://doi.org/10.21833/ijaas.2017.03.018

Skalská, H. (2006). Stochastické modelování (2nd ed.). Gaudeamus.

Sojka, M. (2002). Asymetrické informace a jejich důsledky pro metodologii ekonomie. Ekonomika, Právo a Politika, $4(8), 39-50$.

Soukal, I. (2019). Information quality of web services: Payment account online comparison tools survey in the Czech republic and Slovakia. Information Systems, 341, 244-257. https://doi.org/10.1007/978-3-030-11395-7_21

Soukal, I., \& Draessler, J. (2014). Základní bankovní služby a asymetrie informací z hlediska spotřebitele. Grada.

Soukal, I., \& Draessler, J. (2015). Price Information Asymmetry Impact on Optimal Choice - RCBS Market Case Study. In A. Kocourek (Ed.), Proceedings of the 12th International Conference: Liberec Economic Forum 2015 (pp. 144-153). Technical university of Liberec. 